\title{
Analysis of the Flavobacterium psychrophilum outer-membrane subproteome and identification of new antigenic targets for vaccine by immunomics
}

\section{Correspondence \\ Michel Le Hénaff \\ m-lehenaff@enitab.fr}

Received 10 January 2008

Revised 18 February 2008

Accepted 6 March 2008

\author{
Fabien Dumetz, ${ }^{1} \dagger$ Eric Duchaud, ${ }^{2}$ Stéphane Claverol, ${ }^{3}$ Nicolas Orieux, ${ }^{1}$ \\ Sandrine Papillon, ${ }^{1}$ Delphine Lapaillerie ${ }^{3}$ and Michel Le Hénaff ${ }^{1}$ \\ ${ }^{1}$ Université Bordeaux 1, CNRS UMR 5805 EPOC, Place du Dr Peyneau, F-33120 Arcachon, \\ France \\ ${ }^{2}$ Unité de Virologie et Immunologie Moléculaires, INRA, Domaine de Vilvert, F-78352 \\ Jouy-en-Josas Cedex, France \\ ${ }^{3}$ Plateforme Génomique Fonctionnelle, Université Victor Segalen Bordeaux 2, 146 Rue Léo \\ Saignat, F-33076 Bordeaux Cedex, France
}

\section{INTRODUCTION}

Flavobacterium psychrophilum is a yellow-pigmented, Gram-negative, gliding bacterium that predominantly affects salmonid fish (Borg, 1960), such as coho salmon (Oncorhynchus kisutch) or rainbow trout (Oncorhynchus mykiss), and occasionally other fish species, such as ayu (Plecoglossus altivelis) (Iida \& Mizokami, 1996). This bacterium is therefore responsible for considerable economic losses in fish aquaculture. Infections with $F$. psychrophilum have several clinical manifestations, the most significant of which include mortality associated with haemorrhagic septicaemia and spleen hypertrophy in juvenile fish, referred to as rainbow trout fry syndrome, and in adults, septicaemia preceded by extensive necrotic

†Present address: Institut Pasteur, CNRS URA 2172, Unité des Toxines et Pathogénie Bactérienne, 75015 Paris, France.

Abbreviations: ACN, acetonitrile; ASB-14, 3-[N,N-dimethyl(3-myristoylaminopropyl)ammonio]propanesulfonate; CWD, cold-water disease; GRAVY, grand average of hydropathy; OM, outer membrane; OMP, outer-membrane protein; Sarkosyl, sodium lauryl sarcosinate. lesions, called cold-water disease (CWD) (Bernardet \& Bowman, 2006). However, the actual mechanism of pathogenesis is not well understood, although virulence has been suspected to be related to the ability of $F$. psychrophilum to produce exotoxins (Dalsgaard, 1993), extracellular metalloproteases (Fpp1-2; Secades et al., 2001, 2003) or enzymes involved in the degradation of products such as chondroitin sulfate, collagen and fibrinogen (Bertolini et al., 1994). Clearly, the flavobacterial outer membrane $(\mathrm{OM})$ is important when we consider interactions of bacteria with host cells and tissues in the context of pathogenesis and immunity to infection. Several surface components of $F$. psychrophilum have been implicated in flavobacterial pathogenesis and identified as possible vaccine and diagnostic candidate macromolecules; they include lipopolysaccharide $\mathrm{O}$ antigen (MacLean et al., 2001) and surface-exposed antigens [e.g. $20 \mathrm{kDa}$ antigen (Crump et al., 2001) and OmpA (Merle et al., 2003; Dumetz et al., 2007)], some of which may be good candidates for an F. psychrophilum subunit vaccine, such as the surface-localized Flavobacterium-specific protein (FspA; Crump et al., 2005). Indeed, a protective immune 
response has been shown experimentally in rainbow trout by P18 (Massias et al., 2004), a surface-exposed protein belonging to the OmpH family (Dumetz et al., 2006).

Elucidation of the F. psychrophilum genome sequence has provided information about the structure and function of flavobacterial proteins (Duchaud et al., 2007). Proteomic analysis is a useful approach for examination of global protein synthesis and is particularly good as an indicator of gene expression in bacteria. Such analyses have allowed identification of virulence determinants, antigens and vaccine candidates for many bacterial pathogens (e.g. Pasteurella multocida; Boyce et al., 2006), since changes in the proteome depend on developmental stage, disease state and environmental conditions. Recently, an immunoproteomic analysis of a virulent and a non-virulent strain of $F$. psychrophilum has been done to identify possible factors associated with virulence and to identify specific proteins recognized by the host immune response (Sudheesh et al., 2007). Only minor differences were seen between the two strains when total cell proteins were analysed and four immunogenic proteins were conclusively identified: the heat-shock proteins HSP60 and HSP70, ATP synthase and thermolysin. The ribosomal L10-like protein also seems to elicit a protective response in fish (Crump et al., 2007). Are such antigens promising candidates for vaccine development? Indeed, F. psychrophilum OM preparations (Rahman et al., 2002) and a highly enriched fraction of the surface-exposed antigen $\mathrm{OmpH} / \mathrm{P} 18$ (Dumetz et al., 2006) have been shown previously to be involved in fish protection against infection. Moreover, it has been demonstrated that OM proteins (OMPs) are depleted in two-dimensional (2-D) electrophoresis displaying wholecell extracts (Santoni et al., 2000). The common underrepresentation of OMPs is not only due to their poor solubility, but also sometimes to low expression levels, which renders detection and thus identification difficult. As they are located on the bacterial surface, OMPs are likely to interact with the environment and, particularly, with the host immune system. Therefore, the aims of our study were (i) to perform subcellular fractionation and subsequent enrichment of OMPs with the ionic detergent sodium lauryl sarcosinate (Sarkosyl), (ii) to systematically define the protein content of the $\mathrm{OM}$ from the virulent $F$. psychrophilum strain JIP02/86 and (iii) to identify a number of candidate proteins as possible vaccine targets probed with antibodies collected from naturally infected fish.

\section{METHODS}

F. psychrophilum cell culture. F. psychrophilum strain JIP02/86 (INRA, Jouy-en-Josas, France) was used in this study. Cells were cultured in a modified Anacker \& Ordal's (AOAE) liquid medium supplemented with $5 \%$ bovine serum under standard growth conditions (Dumetz et al., 2006). Purity was checked at the end of growth $\left(\mathrm{OD}_{600}=0.8\right)$ by examination of Gram-stained smears. Cells were collected by centrifugation at $6000 \mathrm{~g}$ for $10 \mathrm{~min}$ at $4{ }^{\circ} \mathrm{C}$. Following removal of supernatant and two washing steps with PBS
(50 mM sodium phosphate buffer, $150 \mathrm{mM} \mathrm{NaCl}, \mathrm{pH} 7.4$ ), the pellet was dispersed into cold water supplemented with a protease inhibitor cocktail (Roche). Flavobacteria were disrupted by 10 repeated ultrasonication steps $\left(24 \mathrm{~W}, 10 \mathrm{~s}, 0{ }^{\circ} \mathrm{C}\right)$. Unbroken cells and cellular debris were removed by centrifugation at $10000 \mathrm{~g}$ for $10 \mathrm{~min}$ at $4{ }^{\circ} \mathrm{C}$. Cell envelopes were recovered by an ultracentrifugation step $\left(260000 \mathrm{~g}, 15 \mathrm{~min}, 4{ }^{\circ} \mathrm{C}\right)$ in a Beckman Coulter MicroUltracentrifuge Optima TLX in TLA-110 rotor. Then they were washed twice with PBS.

Sucrose density-gradient centrifugation. Whole-cell envelope suspension $(200 \mu \mathrm{l}$ per tube) was applied to the discontinuous sucrose density gradient $(20-60 \%$, w/w, sucrose in $5 \mathrm{mM}$ EDTA) reported previously for the separation of inner- and outer-membrane vesicles from Escherichia coli (Osborn \& Munson, 1974). The gradients were ultracentrifuged $\left(215000 \mathrm{~g}, 24 \mathrm{~h}, 4{ }^{\circ} \mathrm{C}\right)$ and fractions were collected by piercing the bottom of each tube with an 18-gauge syringe needle.

OM preparation by differential solubility in Sarkosyl. The OM fraction was isolated from the F. psychrophilum cell envelope with the ionic detergent Sarkosyl (Sigma) as described for the bacterial pathogen Bartonella henselae (Rhomberg et al., 2004). Briefly, wholecell envelopes were dispersed in 1 vol. 10 mM HEPES buffer ( $\mathrm{pH} 7.4$ ) and this envelope suspension was treated with 1 vol. $2 \%$ Sarkosyl in the same buffer at room temperature for $20 \mathrm{~min}$. The insoluble material (i.e. the $\mathrm{OM}$ fraction) was collected by ultracentrifugation and washed twice with HEPES buffer to remove residual traces of detergent contaminants.

Protein and enzyme assays. The OMP content was estimated using our standard procedures (Merle et al., 2003). The OM preparation was finally adjusted to $10 \mathrm{mg}$ protein $\mathrm{ml}^{-1}$ and stored at $-80{ }^{\circ} \mathrm{C}$. $\mathrm{NADH}$ dehydrogenase activity was measured as an indicator for inner-membrane contamination of the OM preparation (Kasahara \& Anraku, 1974).

Electrophoresis. SDS-PAGE analyses were performed in polyacrylamide gel slabs $(10 \times 8 \times 0.075 \mathrm{~cm} ; 10 \%$ acrylamide, $0.26 \%$ bisacrylamide; $200 \mathrm{~V}, 1 \mathrm{~h}$ ) (Laemmli, 1970). 2-D electrophoresis was performed following the ZOOM IPG runner system procedure described by Invitrogen with the following modifications. To generate an electrophoretic map of OMPs, about $200 \mu \mathrm{g}$ protein extract was mixed in $160 \mu \mathrm{l}$ IPG rehydration buffer [7 $\mathrm{M}$ urea, $2 \mathrm{M}$ thiourea, $2 \%$ 3-[N,N-dimethyl(3-myristoylaminopropyl)ammonio]propanesulfonate (ASB-14), $25 \mathrm{mM}$ dithiothreitol, $0.01 \%$ bromophenol blue, $1 \%$, v/v, carrier ampholytes 3-10 (Invitrogen)]. After sonication, samples were clarified by centrifugation $\left(5000 \mathrm{~g}, 5 \mathrm{~min}, 20^{\circ} \mathrm{C}\right)$, loaded on $3-10 \mathrm{NL}$ IPG ZOOM strips (Invitrogen) and allowed to swell overnight. The following IEF parameters were applied: (i) $200 \mathrm{~V}$ for $20 \mathrm{~min}$, (ii) $450 \mathrm{~V}$ for $15 \mathrm{~min}$, (iii) $750 \mathrm{~V}$ for $15 \mathrm{~min}$, and (iv) $2000 \mathrm{~V}$ for $30 \mathrm{~min}$. After the focusing was complete, IPG ZOOM strips were sequentially equilibrated in two equilibration buffers: buffer I ( $6 \mathrm{M}$ urea; $50 \mathrm{mM}$ Tris; $2 \%$ SDS; $30 \%$ glycerol; $50 \mathrm{mM}$ dithiothreitol) and buffer II (6 M urea; $50 \mathrm{mM}$ Tris; $2 \%$ SDS; $30 \%$ glycerol; $125 \mathrm{mM}$ iodoacetamide). The separation in the second dimension was performed on SDS-PAGE $(12 \%$ polyacrylamide) for $2 \mathrm{~h}$ under a constant voltage of $120 \mathrm{~V}$. Following the electrophoretic runs, gels containing proteins were stained with Coomassie brilliant blue G-250.

Protein detection by immunoblotting. Proteins separated by SDSPAGE or by 2-D IEF/SDS-PAGE were electroblotted onto a nitrocellulose filter (Bio-Rad) using a Bio-Rad TransBlot electrophoretic transfer cell as specified by the manufacturer. The blots were blocked with $5 \%$ BSA in PBS for $1 \mathrm{~h}$ at room temperature and then incubated for $1 \mathrm{~h}$ with anti-F. psychrophilum OmpA rabbit serum (Dumetz et al., 2007), with a pool of antisera (dilution 1:2000 in 
$0.05 \%$ Tween 20 in PBS) collected from 20 healthy trout (generously given by Scott E. LaPatra, Clear Springs Foods, Inc., Buhl, Idaho, USA) or with a pool of antisera (dilution $1: 1000$ in $0.05 \%$ Tween 20 in PBS) collected from 20 CWD-convalescent trout taken from an infected French farm. The washing steps were performed three times with PBS-Tween 20. An additional incubation was made with a rabbit antiserum anti-trout immunoglobulin (dilution $1: 2000$ ); the primary antibodies were from trout antiserum. Bound antibodies were visualized on immunoblots using an incubation step with alkaline phosphatase-conjugated anti-rabbit IgG antibodies (dilution $1: 2000$; DakoCytomation), followed by a colour reaction with an NBT/BCIP cocktail (4-nitroblue tetrazolium chloride; 5-bromo-4-chloro-3indolyl phosphate).

\section{Protein identification by LC-MS/MS, data interpretation and} database searching. Protein spots selected for analysis were manually excised from the 2-D gels and destained in $\mathrm{H}_{2} \mathrm{O}$ /acetonitrile $(\mathrm{ACN})(50: 50)$. Spots were subsequently rinsed twice in ultrapure water and shrunk in ACN for 10 min. After removal of ACN, gel pieces were dried at room temperature, covered with trypsin solution $\left(10 \mathrm{ng} \mathrm{ml}^{-1}\right.$ in $\left.50 \mathrm{mM} \mathrm{NH}_{4} \mathrm{HCO}_{3}\right)$, rehydrated at $4{ }^{\circ} \mathrm{C}$ for $10 \mathrm{~min}$ and finally incubated overnight at $37{ }^{\circ} \mathrm{C}$. Spots were then incubated for $15 \mathrm{~min}$ in $50 \mathrm{mM} \mathrm{NH}_{4} \mathrm{HCO}_{3}$ at room temperature with rotary shaking. The supernatant was collected and an $\mathrm{H}_{2} \mathrm{O} / \mathrm{ACN} / \mathrm{HCOOH}$ $(47.5: 47.5: 5)$ extraction solution was added onto the gel slices and left for $15 \mathrm{~min}$. The extraction step was repeated twice. Supernatants were pooled and concentrated in a vacuum centrifuge to a final volume of $25 \mu$ l. Digests were finally acidified by addition of $1.5 \mu \mathrm{l}$ $5 \%$ acetic acid and stored at $-20{ }^{\circ} \mathrm{C}$. The peptide mixture was analysed by online capillary HPLC $(300 \mu \mathrm{m} \times 5 \mathrm{~mm}$ C18 PepMap trap column; LC Packings) coupled to a nanospray LCQ IT mass spectrometer (Thermo Finnigan). The samples used were $10 \mu$ of the peptide digests. The flow rate was set at $200 \mathrm{nl} \mathrm{min}^{-1}$. Solvent A was used for column equilibration $(0.1 \%$ formic acid in $5 \% \mathrm{ACN})$ and solvent B was $0.1 \%$ formic acid in $80 \%$ ACN. Peptides were eluted with a $5-50 \%$ linear gradient of solvent B for $30 \mathrm{~min}$. The mass spectrometer operated in positive ion mode at a $2 \mathrm{kV}$ needle voltage and a $46 \mathrm{~V}$ capillary voltage. Data were acquired in data-dependent mode alternating an MS scan survey over the range $\mathrm{m} / z$ 300-2000 and three MS/MS scans in an exclusion dynamic mode. MS/MS spectra were acquired using a $2 \mathrm{~m} / z$ units ion isolation window, a $35 \%$ relative collision energy and a 0.5 min dynamic exclusion duration. Data were searched by SEQUEST through the Bioworks 3.2 interface (Thermo Finnigan) against the F. psychrophilum complete proteome database (Duchaud et al., 2007). Data files were generated for MS/MS spectra that reached both a minimal intensity $\left(5 \times 10^{4}\right)$ and a sufficient number of ions (Fraser et al., 1999). Generation of the data file allowed the averaging of several MS/MS spectra corresponding to the same precursor ion with a tolerance of $1.4 \mathrm{Da}$. Spectra from precursor ions higher than $3500 \mathrm{Da}$ or lower than $500 \mathrm{Da}$ were rejected. The search parameters were as follows: mass accuracy of the peptide precursor and peptide fragments was set to $1.5 \mathrm{Da}$ and $0.5 \mathrm{Da}$, respectively. Only b- and y-ions were considered for mass calculation. Oxidation of methionines $(+16)$ and carbamidomethylation of cysteines $(+57)$ were considered as differential modifications. Two missed trypsin cleavages were allowed. Only peptides with Xcorr values higher than 1.5 (single charge), 2 (double charge) and 2.5 (triple charge) were retained. In all cases, $\Delta C_{n}$ had to be greater than 0.1 . All protein identifications were based on a minimum of two peptide assignments. To be considered, the protein spot had to show a reproducible pattern in three gels which had been run separately.

In silico analysis. Protein homology searches were carried out with the SWISS-PROT database with the BLAST (Altschul et al., 1990; Schäffer et al., 2001) and FASTA (Pearson, 1990) algorithms. Identification of peculiar domains in proteins was conducted using the HMMPFAM program in the HMMER package with the Pfam HMM library (www.sanger.ac.uk/Software/Pfam/) (Finn et al., 2006). Prediction of membrane-spanning regions and their orientation was performed using the TMpred program (Hofmann \& Stoffel, 1993). Membrane anchor and signal peptides were analysed with LipoP 1.0 and SignalP 3.0 software (www.cbs.dtu.dk/services/) (Nielsen et al., 1997; Juncker et al., 2003; Bendtsen et al., 2004). The subcellular locations of OM candidates were predicted using the program PSORTb v. 2.0 (www.psort.org/psortb/) (Gardy et al., 2005). The hydrophobicity of proteins was estimated using the grand average of hydropathy (GRAVY) value (ProtParam program; ExPASy proteomics tools, www.expasy.org/tools/protparam.html) as the sum of the hydropathy value of all amino acids divided by the length of the amino acid sequence (Kyte \& Doolittle, 1982).

\section{RESULTS AND DISCUSSION}

\section{OMPs preparation}

High-quality subcellular fractionation was a prerequisite for a proteomic analysis of the OM subproteome. First, we tried to isolate OMs from the whole-cell envelope of $F$. psychrophilum JIP02/86 using discontinuous sucrose gradient ultracentrifugation. This method was not fruitful, since only one layer containing the envelope material was seen in the gradient, even when the gradient curves were modified (data not shown). Consequently, the ionic detergent Sarkosyl was used on an F. psychrophilum cellenvelope suspension (Fig. 1) because of its capability to selectively release proteins from the inner membrane of ruptured Gram-negative bacteria while conserving the integrity of the OM. The purity of the OM preparation (Fig. 1a; lane 2) was shown by immunoblot analysis using antibodies directed against an OM-specific marker (OmpA; Dumetz et al., 2007) and by an enzymic assay using NADH dehydrogenase activity as an inner-membrane marker (Fig. 1b). The signal for OmpA could only be seen in the OM preparation, whereas NADH dehydrogenase activity could only be detected in the Sarkosyl-soluble fraction. This isolation method results in a sufficiently pure $\mathrm{OM}$ fraction since no NADH dehydrogenase activity was recorded, underlining the absence of cytoplasmic membrane contaminants.

\section{2-D electrophoresis of F. psychrophilum OMPs and protein assignment}

OMs prepared by Sarkosyl insolubility were used for concise 2-D mapping of $F$. psychrophilum JIP02/86 OMPs (Fig. 2a). Using the non-ionic detergent ASB-14, proteins were solubilized and resolved within a non-linear $\mathrm{pH}$ range of 3-10. A total of 34 OMP spots were selected from the 2$\mathrm{D}$ gel. LC-MS/MS analysis of these spots allowed the identification of 36 ORFs comprising $1.5 \%$ of the 2432 predicted protein-encoding genes in F. psychrophilum (Table 1). All of the detected spots were resolved within a molecular mass range of $<120$ to about $18 \mathrm{kDa}$.

Identified proteins were analysed for hydrophobicity by determining their GRAVY scores. A calculated GRAVY score of up to -0.4 indicates a hydrophobic protein, 
(a)

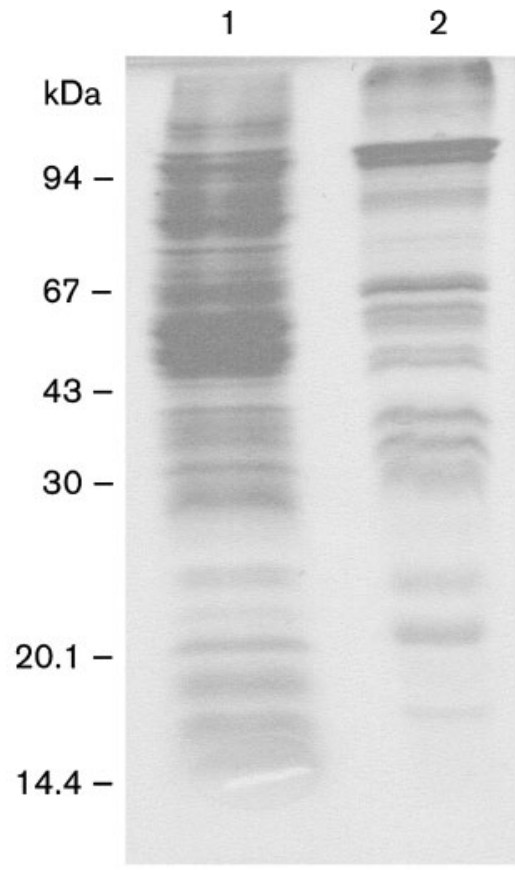

(b)

1

2

3

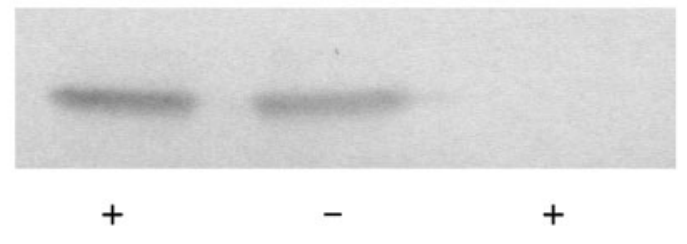

Fig. 1. SDS-PAGE analysis of $F$. psychrophilum JIP02/86 proteins. Lanes: $1(\mathrm{a}, \mathrm{b})$, cell-envelope fraction $(20 \mu \mathrm{g}$ protein); 2 (a, b), Sarkosyl-insoluble OM fraction (10 $\mu$ g protein); 3 (b), Sarkosyl-soluble inner-membrane fraction $(10 \mu \mathrm{g}$ protein). All samples were solubilized with $1 \%$ SDS. Proteins were silverstained (a) or probed with a rabbit antiserum directed against OmpA (b). NADH dehydrogenase activity in each fraction is indicated by + or - under each in (b).

suggesting a membrane association. Here, such a criterion revealed that $75 \%$ of the proteins identified in the course of the 2-D analysis should be considered to be hydrophobic (Table 1). It should be stressed that even with a score of $<-0.4$, a protein might still be membrane-associated as has been shown for some lipoproteins; such hydrophilic components that carry out functions on the membrane surface are tethered to the plasma membrane via acyl chains (e.g. OspA from Borrelia burgdorferi, Bouchon et al., 1997; spiralin from Spiroplasma melliferum, Le Hénaff \& Fontenelle, 2000). Sixteen of the identified proteins are predicted to be OMs, but the subcellular location could not be determined for the 20 other identified spots. However, the identity of some spots suggests that the OM fraction might have been weakly contaminated by cytoplasmic and/or periplasmic components: a probable cytoplasmic cysteine aminopeptidase (spot 16, FP2369; PepC, the bacterial homologue of the eukaryotic bleomycin hydrolase; Mistou \& Gripon, 1998) and a protein of unknown function (spot 24, FP1439; FkpA/FKBP-type, a possible homologue of an Escherichia coli periplasmic chaperone; Saul et al., 2004).

Our earlier observations (Duchaud et al., 2007) suggest that the Sec system is the major route contributing to the export of proteins across the plasma membrane. All identified proteins were predicted to contain typical Sec signal N-termini lacking sequence similarity. Twenty-one out of the 36 identified proteins seem to be synthesized as a proprotein containing a typical signal peptide (about $20 \mathrm{aa})$ with a cleavage specific for signal peptidase I (SPase I). The 15 other spots are proteins predicted to be processed in the same way as Braun's lipoprotein, the prototype for bacterial lipoproteins (Sankaran et al., 1995), since they contain a putative cleavage site for the prolipoprotein-specific signal peptidase II (globomycinsensitive SPase II). A few proteins were resolved as multiple spots, as shown in Fig. 2(a) (e.g. spot 13, OmpA, FP0156). This might be due to post-translational modifications. Indeed, such modifications can modify the pI while the apparent molecular masses of the proteins are not affected, since the modifications are mainly on the side chains of the amino acids. Heterogeneous sugar modifications do explain the large multiple spots seen for OmpA since it is a glycoprotein (Merle et al., 2003). Spots assembled into a single circle were also identified as OmpA, although their molecular masses were less than $30 \mathrm{kDa}$, suggesting possible degradation in the course of sample preparation. Interestingly, a probable lipoprotein precursor of an uncharacterized iron-regulated protein (spot 20, FP1478, IrpA) was found as two spots with a difference in their apparent molecular mass of less than $3 \mathrm{kDa}$, suggesting its presence in the $\mathrm{OM}$ in both unprocessed and processed forms. However, the Sec-independent system must be functional since we have previously identified one possible component of the type 1 secretion system from Sarkosylinsoluble membrane proteins resolved by 1-D electrophoresis (probable multidrug resistance protein, AcrB/AcrD/ AcrF family protein, FP0880; Dumetz, 2006) and the gene encoding a probable OM efflux protein TolC (FP0296) is present in the F. psychrophilum genome (Duchaud et al., 2007). In Gram-negative bacteria, TolC efflux has been described as a tripartite pump that consists of the TolC OMP and a specific plasma membrane channel (such as AcrB) connected with a periplasmic protein known as the adaptor (e.g. AcrA) (Fernandez-Recio et al., 2004).

Iron import is often the limiting factor in bacterial growth, largely because of the insolubility of $\mathrm{Fe}(\mathrm{III})$, but also because mammals reduce the availability of iron to potential pathogens by the use of very high affinity ironchelating molecules (lactoferrin, transferrin and haemoglobin) (for a review see Bullen et al., 2005). As a consequence, host-adapted pathogens have evolved means of using these iron-bearing molecules as an iron source, as well as in some cases synthesizing their own chelators 


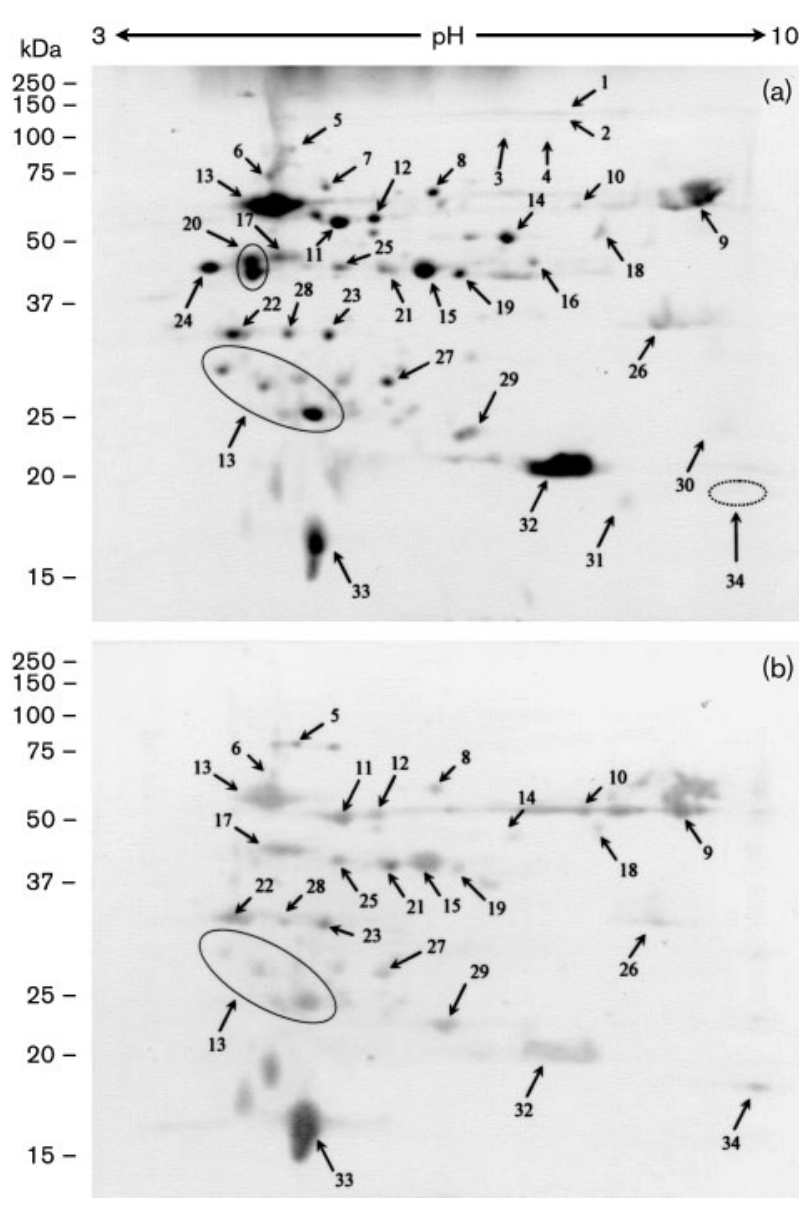

Fig. 2. 2-D gel map of $F$. psychrophilum JIP02/86. Proteins were prepared from Sarkosyl-insoluble OM material (see Methods) and resolved using non-linear $\mathrm{pH}$ 3-10 IPG and 12\% SDS-PAGE. Proteins were stained with Coomassie brilliant blue G-250 (a) or probed with a pool of antisera collected from CWD-convalescent trout (b). Protein spots are annotated according to FPORF (F. psychrophilum gene annotation; Duchaud et al., 2007).

(siderophores), which are secreted, trap iron and are then transported back into the cell. Interestingly, we found seven proteins in the $\mathrm{OM}$ of $F$. psychrophilum which may be involved in iron acquisition/metabolism. They include a probable OMP belonging to the Omp121 family (FP1199), five probable TonB-dependent OM receptors (FP0144, FP1500, FP2456, FP1922 and FP0521), and iron-regulated protein A (IrpA, FP1478). Genes encoding such components have been identified in bacteria belonging to the Cytophaga-Flavobacterium-Bacteroides phylum (e.g. omp200, a porin gene complex from Bacteroides fragilis, omp121 and omp71; Wexler et al., 2002). Because of the importance of iron to the survival of bacterial pathogens within the host environment, the TonB system has been shown to be essential for virulence in diverse organisms (Beddek et al., 2004; Wyckoff et al., 2006) and components are the main targets of the humoral immune response (e.g. the siderophore receptor FhuA in Haemophilus parasuis; del Río et al., 2006). However, functional studies are needed to assign possible roles of these components to iron acquisition and flavobacterial virulence.

Analysis of the $\mathrm{OM}$ proteome indicated four spots that were identified as probable cell-surface proteins containing leucine-rich repeats (Lrr proteins: FP0169, FP0171, FP0172 and FP0175). Leucine-rich repeats consist of 2-45 motifs of 20-30 aa in length (Enkhbayar et al., 2004) and appear to provide a structural framework for the formation of protein-protein interactions (Kobe \& Kajava, 2001). Proteins containing Lrr include cell-adhesion molecules, virulence factors and extracellular matrix-binding glycoproteins, involved in a variety of biological processes (signal transduction, cell adhesion, disease resistance, immune response, etc.). The four Lrr proteins identified in F. psychrophilum are encoded by four genes belonging to a family of 15 genes (Duchaud et al., 2007). They show similarities with BspA and LrrA from the periodontopathogenic bacteria Tannerella forsythensis (Inagaki et al., 2005, 2006) and Treponema denticola (Ikegami et al., 2004), respectively. These proteins have been reported to be immunogenic cell-surface determinants that bind strongly to extracellular matrix components and play a role in the attachment to human oral tissue, a property that may be important in the virulence of these organisms.

Several known proteins have been retrieved from the OM preparation. They are OmpH/P18 (FP2098; Massias et al., 2004; Dumetz et al., 2006), OmpA (FP0156; Merle et al., 2003; Dumetz et al., 2007) and flavobacterial-specific protein antigen (FspA) (FP2019; Crump et al., 2005). All of them are probably involved in bacteria-host interactions since they are included in a set of antigenic flavobacterial proteins recognized predominantly by antisera from convalescent fish that were naturally infected. Several other proteins and lipoproteins with unknown functions were found (see Table 1). They include a flavomodulin (FP0097) that could be a member of the thiol-activated cytolysin family of pore-forming toxins (TACYs). Such toxins are involved in the pathogenesis mechanism of a number of Gram-positive species of bacteria, such as suilysin from Streptococcus suis (Lun et al., 2003). They may interfere with immune cell function and induce cytokine production (Billington et al., 2000). In F. psychrophilum, flavomodulin may be present because of a possible lateral gene transfer event from a Gram-positive bacterium, and it may be related to flavobacterial virulence as has been shown for suilysin (Takamatsu et al., 2002).

\section{Immunogenic OMPs of $\boldsymbol{F}$. psychrophilum}

The OM fraction prepared by Sarkosyl insolubility was used for identification of immunoreactive proteins using a pool of antisera collected from CWD-convalescent trout. A total of 25 immunolabelled protein spots were observed from the immunoblot (Fig. 2b) and they matched the protein spots seen in the preparative 2-D gel (Fig. 2a). No immunoreactive 
Table 1. Protein identification in the OM of F. psychrophilum JIP02/86

Assignment of single spots to the locus tag of the complete F. psychrophilum genome. Putative cleavage sites for signal peptides, subcellular location and possible transmembrane helices were predicted using SignalP, PSORTb or ExPASy proteomics tools, respectively.

\begin{tabular}{|c|c|c|c|c|c|c|c|c|c|}
\hline $\begin{array}{l}\text { Spot } \\
\text { no }\end{array}$ & NCBI acc. no & Protein description & $\begin{array}{l}\text { Peptide } \\
\text { matching }\end{array}$ & $\begin{array}{l}\text { Sequence } \\
\text { coverage }\end{array}$ & $\begin{array}{l}\mathrm{pI} / \text { molecular } \\
\text { mass }(\mathrm{kDa})\end{array}$ & $\begin{array}{l}\text { GRAVY } \\
\text { score }\end{array}$ & $\begin{array}{c}\text { Putative } \\
\text { cleavage site }\end{array}$ & $\begin{array}{l}\text { Subcellular } \\
\text { location }\end{array}$ & $\begin{array}{l}\text { Transmem- } \\
\text { brane helix }\end{array}$ \\
\hline 1 & FP1199 & Probable OMP (Omp121 family) & $136 / 22$ & 25.8 & $8.94 / 115.1$ & -0.285 & SpI $22-23$ & OM & 0 \\
\hline 2 & FP0144 & $\begin{array}{l}\text { Probable TonB-dependent OM } \\
\text { receptor }\end{array}$ & $64 / 36$ & 51.6 & $9.04 / 104.9$ & -0.431 & SpI $18-19$ & $\mathrm{OM}$ & 1 \\
\hline 3 & FP2096 & Probable OMP & $35 / 25$ & 35.1 & $9.13 / 99.9$ & -0.437 & SpI 21-22 & $\mathrm{OM}$ & 0 \\
\hline 4 & FP1500 & $\begin{array}{l}\text { Probable TonB-dependent OM } \\
\text { receptor }\end{array}$ & $27 / 22$ & 37.1 & $9.21 / 92.2$ & -0.556 & SpI $19-20$ & $\mathrm{OM}$ & 0 \\
\hline 5 & FP2456 & $\begin{array}{l}\text { Probable TonB-dependent OM } \\
\text { ferrichrome-iron receptor }\end{array}$ & $13 / 13$ & 21.1 & $8.98 / 86.5$ & -0.290 & SpII 19-20 & $\mathrm{OM}$ & 0 \\
\hline- & FP0690 & $\begin{array}{l}\text { Putative OMP involved in nutrient } \\
\text { binding }\end{array}$ & $17 / 17$ & 29.7 & $9.22 / 89.5$ & -0.368 & SpI 21-22 & $\mathrm{OM}$ & 1 \\
\hline 6 & FP1922 & $\begin{array}{l}\text { Probable TonB-dependent OM } \\
\text { ferrichrome-iron receptor FhuA }\end{array}$ & $19 / 18$ & 35.7 & $9.19 / 83.2$ & -0.300 & SpI 20-21 & $\mathrm{OM}$ & 0 \\
\hline 7 & FP0521 & $\begin{array}{l}\text { Probable TonB-dependent OM } \\
\text { receptor }\end{array}$ & $22 / 17$ & 40.4 & $9.18 / 66.3$ & -0.324 & SpI 18-19 & OM & 0 \\
\hline 8 & FP0110 & $\begin{array}{l}\text { Probable lipoprotein of unknown } \\
\text { function }\end{array}$ & $105 / 21$ & 46.2 & $6.35 / 60.7$ & -0.225 & SpII 21-22 & Unknown & 0 \\
\hline 9 & FP1198 & $\begin{array}{l}\text { Probable lipoprotein of unknown } \\
\text { function }\end{array}$ & $105 / 15$ & 37.8 & $8.18 / 58.3$ & -0.066 & SpII 19-20 & Unknown & 0 \\
\hline 10 & FP1402 & Protein of unknown function & $36 / 16$ & 42.4 & $9.03 / 56.4$ & -0.462 & SpI 19-20 & $\mathrm{OM}$ & 0 \\
\hline 11 & FP1346 & $\begin{array}{l}\text { Probable lipoprotein of unknown } \\
\text { function }\end{array}$ & $166 / 23$ & 57.9 & $5.49 / 54.5$ & -0.346 & SpII $20-21$ & Unknown & 1 \\
\hline 12 & FP2239 & $\begin{array}{l}\text { Probable lipoprotein of unknown } \\
\text { function }\end{array}$ & $93 / 10$ & 27.6 & $5.61 / 50.4$ & -0.155 & SpII $18-19$ & Unknown & 1 \\
\hline 13 & FP0156 & OMP P60 (OmpA family) & $364 / 32$ & 68.6 & $4.57 / 49.4$ & -0.324 & SpI 21-22 & $\mathrm{OM}$ & 0 \\
\hline 14 & FP0073 & Protein of unknown function & $15 / 13$ & 40.2 & $6.68 / 46.3$ & -0.248 & SpI $22-23$ & Unknown & 0 \\
\hline 15 & FP1486 & $\begin{array}{l}\text { Probable lipoprotein of unknown } \\
\text { function }\end{array}$ & $215 / 19$ & 56.1 & $5.61 / 44.7$ & -0.168 & SpII 18-19 & Unknown & 0 \\
\hline 16 & FP2369 & $\begin{array}{l}\text { Bleomycin hydrolase } \\
\text { minopeptidase C }\end{array}$ & $68 / 22$ & 63.8 & $5.97 / 44.2$ & -0.454 & SpI 21-22 & Unknown & 0 \\
\hline 17 & FP0175 & $\begin{array}{l}\text { Probable cell-surface protein } \\
\text { (Lrr protein) }\end{array}$ & $6 / 4$ & 14.7 & $5.26 / 44.1$ & +0.321 & SpI $16-17$ & Unknown & 1 \\
\hline 18 & FP2433 & $\begin{array}{l}\text { Protein of unknown function, } \\
\text { putative OMP }\end{array}$ & $17 / 11$ & 27.0 & $9.58 / 43.6$ & -0.067 & SpI 19-20 & $\mathrm{OM}$ & 1 \\
\hline 19 & FP2425 & $\begin{array}{l}\text { Probable lipoprotein of unknown } \\
\text { function }\end{array}$ & $20 / 12$ & 42.0 & $5.70 / 43.4$ & -0.480 & SpII-17-18 & Unknown & 0 \\
\hline 20 & FP1478 & Probable lipoprotein IrpA & $137 / 15$ & 49.2 & $4.88 / 42.4$ & -0.132 & SpII $18-19$ & $\mathrm{OM}$ & 0 \\
\hline 21 & FP0097 & Flavomodulin & $27 / 11$ & 32.2 & $8.26 / 42.0$ & -0.185 & SpII $18-19$ & $\mathrm{OM}$ & 0 \\
\hline 22 & FP1456 & Probable lipoprotein ('S-layer') & $106 / 10$ & 32.6 & $5.33 / 37.8$ & +0.074 & SpII 19-20 & Unknown & 0 \\
\hline $23^{*}$ & FP0171 & $\begin{array}{l}\text { Probable cell surface protein } \\
\text { (Lrr protein) }\end{array}$ & $17 / 3$ & 13.8 & $8.88 / 30.3$ & +0.239 & SpI $18-19$ & Unknown & 1 \\
\hline- & FP0172 & $\begin{array}{l}\text { Probable cell-surface protein } \\
\text { (Lrr protein) }\end{array}$ & $17 / 3$ & 11.1 & $8.04 / 37.2$ & +0.305 & SpI $18-19$ & Unknown & 1 \\
\hline 24 & FP1439 & $\begin{array}{l}\text { Protein of unknown function } \\
\text { (FKBP-type) }\end{array}$ & $60 / 9$ & 28.4 & $4.73 / 37.2$ & -0.506 & SpII 19-20 & Unknown & 0 \\
\hline 25 & FP0169 & $\begin{array}{l}\text { Probable cell-surface protein } \\
\text { (Lrr protein) }\end{array}$ & $12 / 3$ & 11.8 & $7.55 / 35.3$ & +0.284 & SpI $16-17$ & Unknown & 0 \\
\hline 26 & FP0261 & Protein of unknown function & $136 / 15$ & 54.5 & $7.82 / 34.0$ & -0.323 & SpI 19-20 & $\mathrm{OM}$ & 1 \\
\hline 27 & FP0578 & Protein of unknown function & $57 / 9$ & 34.7 & $6.10 / 29.4$ & -0.010 & SpII $20-21$ & Unknown & 1 \\
\hline 28 & FP0451 & Protein of unknown function & $38 / 10$ & 28.7 & $8.69 / 26.0$ & -0.593 & SpII $18-19$ & Unknown & 0 \\
\hline 29 & FP2138 & Protein of unknown function & $6 / 6$ & 31.6 & $5.73 / 26.2$ & -0.333 & SpI $16-17$ & Unknown & 1 \\
\hline 30 & FP1507 & Probable lipoprotein YiaD precursor & $12 / 5$ & 29.4 & $9.06 / 23.9$ & -0.217 & SpII $21-22$ & $\mathrm{OM}$ & 3 \\
\hline 31 & FP1493 & Protein of unknown function & $111 / 9$ & 65.9 & $8.61 / 22.7$ & -0.015 & SpII $19-20$ & Unknown & 0 \\
\hline 32 & FP2019 & $\begin{array}{l}\text { Flavobacterial-specific protein } \\
\text { antigen FspA }\end{array}$ & $176 / 12$ & 83.3 & $9.35 / 21.3$ & +0.017 & SpI $19-20$ & Unknown & 1 \\
\hline 33 & FP0139 & Protein of unknown function & $164 / 7$ & 32.7 & $7.87 / 18.4$ & +0.027 & SpI $18-19$ & $\mathrm{OM}$ & 0 \\
\hline 34 & FP2098 & OMP P18 (OmpH family) & $35 / 7$ & 48.8 & $8.58 / 18.7$ & -0.456 & SpI $23-24$ & Unknown & 1 \\
\hline
\end{tabular}

*The peptides identified here did not allow us to differentiate the probable cell-surface proteins FP0171 and FP0172. 
spot was observed when a pool of antisera obtained from healthy trout was used to probe the blot (data not shown).

The first group of proteins identified in the study included strong immunogens which have been previously wellcharacterized in F. psychrophilum: (i) FspA, (ii) the OmpA family, and (iii) OmpH/P18 (see above). As expected, these proteins comprise some of the major, abundant protein spots on the 2-D immunoblot. It should be stressed that the protein spot corresponding to $\mathrm{OmpH} / \mathrm{P} 18$ was very poorly stained with Coomassie brilliant blue R-250 (see circle with dashed line, Fig. 2a), whereas it was visible clearly on the immunoblot (Fig. 2b). As a surface-adsorbed protein (Dumetz et al., 2006), OmpH/P18 should be lost during the Sarkosyl treatment of cell envelopes during preparation of the OM fraction. In Gram-negative bacteria, OmpA is highly abundant in the cell wall and is involved in several functions, including the ability of bacteria to invade host cells (adhesin, invasin), to participate in biofilm formation and to act as both an immune target and an evasin. Many of these properties are related to four short protein loops that emanate from the protein to the outside of the cell (for a review see Smith et al., 2007). Although the $\mathrm{N}$-terminal amino acid sequence of $F$. psychrophilum OmpA shows no similarity with any other OMPs of Gramnegative bacteria outside of the family Flavobacteriaceae, we have recently shown that OmpA contains five possible thrombospondin type 3 repeat: OmpA/MotB domains, suggesting that it might be involved in the interaction/ adherence of the pathogen with the host cells, as for other members of the OmpA family (Dumetz et al., 2007). In addition, OmpA is one of the immunodominant antigens, and antibodies raised against it are capable of killing flavobacterial cells in the presence of complement. Preliminary data suggest also that vaccine cocktails containing OmpA protect rainbow trout against flavobacteriosis. The surface-localized protein FspA was first identified since it reacts strongly with serum from CWDconvalescent fish (Crump et al., 2005). As for OmpA, FspA was shown to be unique and only homologous to unspecified sequences reported from bacteria belonging to the family Flavobacteriaceae. However, weak sequence homologies were found with a $17 \mathrm{kDa}$ OMP from Yersinia pseudotuberculosis that mediates adhesion to mammalian cells and contributes to serum resistance (Yang et al., 1996). Taking these data as a whole, proteins from this group appear to be the main immunogens, widely exposed at the cell surface of F. psychrophilum and, consequently, are the most promising subunit candidates for vaccine design. However, functional studies are needed to clarify their functions, particularly their interactions with host cells and their capabilities to stimulate the immune system.

The second group consisted mainly of a large set of probable proteins or lipoproteins of unknown function, for which there is no homologous equivalent in microorganisms outside the Cytophaga-FlavobacteriumBacteroides phylum. However, it contained the four probable cell-surface proteins with leucine-rich repeats identified above that show similarities to BspA and LrrA proteins from Tannerella forsythensis and Treponema denticola, respectively. Like BspA and LrrA proteins, we have reported here that Lrr proteins in F. psychrophilum are immunogenic cell-surface determinants. They might play an important role in attachment to fish tissues, as do their homologues from periodontopathogens which bind strongly to extracellular matrix components (Sharma et al., 1998; Ikegami et al., 2004). The identification of such components belonging to the second group of immunoreactive proteins provides a set of novel antigens that could be unique to F. psychrophilum and a useful reservoir for the design of new vaccines. Biochemical characterization is required to establish the function of FP0139 (corresponding to spot 33; Fig. 2) which seems to be a good antigenic candidate. Indeed, the CWD-convalescent trout antisera contain a high titre of antibodies directed against this protein, as suggested by the intensity of the immunolabelled spot. The question concerning the protective activity of such antibodies remains open.

In conclusion, an objective of proteomic investigation concerning the study of bacterial pathogens is the location of proteins within or near the cell surface. Such proteins are known to have pivotal functions related to adhesion and invasion of host tissues, weakening of the host immune response and acquisition of host metabolites necessary for bacterial survival. Consequently, OMPs are good vaccine candidates, since they are usually abundant proteins and are in direct contact with the host immune system. In this study, we have mapped the OM proteome and identified 25 proteins that can elicit a humoral immune response by rainbow trout. Several of them have been identified previously and used as subunit vaccines for experimental challenge/vaccine assays (e.g. OmpH/P18; Dumetz et al., 2006). More interestingly, this study draws up an inventory of new $F$. psychrophilum immunoreactive proteins that may be used either as single antigens or in combinations of several surface-exposed antigens. Further work is needed to evaluate the capability of these components to induce high titres of protective antibodies and their protection efficacy upon challenge with $F$. psychrophilum in fish.

\section{ACKNOWLEDGEMENTS}

We would like to thank Anne-Marie Richard from Enitab for excellent technical assistance, Daniel Jacob from INRA, Centre de BioInformatique de Bordeaux, for his help in the analysis of the $F$. psychrophilum complete proteome database, and Scott E. LaPatra, Clear Springs Foods, Inc., Buhl, Idaho, USA, for the generous gift of antisera collected from healthy trout. This work was partly sponsored by grants from the Région Aquitaine, from the Ecole Doctorale Université Victor Segalen Bordeaux 2/Ministère de la Recherche and from the Enita-Bordeaux.

\section{REFERENCES}

Altschul, S. F., Gish, W., Miller, W., Myers, E. W. \& Lipman, D. J. (1990). Basic local alignment search tool. J Mol Biol 215, 403-410. 
Beddek, A. J., Sheehan, B. J., Bossé, J. T., Rycroft, A. N., Kroll, J. S. \& Langford, P. R. (2004). Two TonB systems in Actinobacillus pleuropneumoniae: their roles in iron acquisition and virulence. Infect Immun 72, 701-708.

Bendtsen, J. D., Nielsen, H., von Heijne, G. \& Brunak, S. (2004). Improved prediction of signal peptides: SignalP 3.0. J Mol Biol 340, 783-795.

Bernardet, J.-F. \& Bowman, J. P. (2006). The genus Flavobacterium. In The Prokaryotes: an Evolving Electronic Resource for the Microbiological Community, 3rd edn. Edited by M. Dworkin \& others. New York: Springer.

Bertolini, J. M., Wakabayashi, H., Watral, V. G., Whipple, M. J. \& Rohvec, J. S. (1994). Electrophoretic detection of proteases from selected strains of Flexibacter psychrophilus and assessment of their variability. J Aquat Anim Health 6, 224-233.

Billington, S. J., Jost, B. H. \& Songer, J. G. (2000). Thiol-activated cytolysins: structure, function and role in pathogenesis. FEMS Microbiol Lett 182, 197-205.

Borg, A. F. (1960). Studies on Myxobacteria Associated with Diseases in Salmonid Fishes. Wildlife Disease No. 8. Washington, DC: American Association for the Advancement of Science.

Bouchon, B., Klein, M., Bischoff, R., Van Dorsselaer, A. \& Roitsch, C. (1997). Analysis of the lipidated recombinant outer surface protein $A$ from Borrelia burgdorferi by mass spectrometry. Anal Biochem 246, 52-61.

Boyce, J. D., Cullen, P. A., Nguyen, V., Wilkie, I. \& Adler, B. (2006). Analysis of the Pasteurella multocida outer membrane sub-proteome and its response to the in vivo environment of the natural host. Proteomics 6, 870-880.

Bullen, J. J., Rogers, H. J., Spalding, P. B. \& Ward, C. G. (2005). Iron and infection: the heart of the matter. FEMS Immunol Med Microbiol 43, 325-330.

Crump, E. M., Perry, M. B., Clouthier, S. C. \& Kay, W. W. (2001). Antigenic characterization of the fish pathogen Flavobacterium psychrophilum. Appl Environ Microbiol 67, 750-759.

Crump, E. M., Burian, J., Allen, P. D. \& Kay, W. W. (2005). Identification and expression of a host-recognized antigen, FspA, from Flavobacterium psychrophilum. Microbiology 151, 3127-3135.

Crump, E. M., Burian, J., Allen, P. D., Gale, S. \& Kay, W. W. (2007). Identification of a ribosomal L10-like protein from Flavobacterium psychrophilum as a recombinant vaccine candidate for rainbow trout fry syndrome. J Mol Microbiol Biotechnol 13, 55-64.

Dalsgaard, I. (1993). Virulence mechanisms in Cytophaga psychrophila and other Cytophaga-like bacteria pathogenic for fish. In Annual Review of Fish Diseases, pp. 127-144. Edited by M. Faisal \& F. M. Hetrick. New York, NY: Pergamon Press.

del Río, M. L., Navas, J., Martín, A. J., Gutiérrez, C. B., RodríguezBarbosa, J. I. \& Rodríguez Ferri, E. F. (2006). Molecular characterization of Haemophilus parasuis ferric hydroxamate uptake $(f h u)$ genes and constitutive expression of the FhuA receptor. Vet Res 37, 49-59.

Duchaud, E., Boussaha, M., Loux, V., Bernardet, J.-F., Michel, C., Kerouault, B., Mondot, S., Nicolas, P., Bossy, R. \& other authors (2007). Complete genome sequence of the fish pathogen Flavobacterium psychrophilum. Nat Biotechnol 25, 763-769.

Dumetz, F. (2006). Les antigènes de surface de Flavobacterium psychrophilum: approche protéomique et caractérisation de deux protéines (OmpA/P60 et OmpH/P18) immunoprotectrices. $\mathrm{PhD}$ thesis. University Victor Segalen Bordeaux 2, Bordeaux, France.

Dumetz, F., Duchaud, E., LaPatra, S.-E., Le Marrec, C., Claverol, S., Urdaci, M. C. \& Le Hénaff, M. (2006). A protective immune response is generated in rainbow trout by an $\mathrm{OmpH}$-like surface antigen (P18) of Flavobacterium psychrophilum. Appl Environ Microbiol 72, 48454852.

Dumetz, F., LaPatra, S.-E., Duchaud, E., Claverol, S. \& Le Hénaff, M. (2007). The Flavobacterium psychrophilum OmpA, an outer membrane glycoprotein, induces a humoral response in rainbow trout. $J$ Appl Microbiol 103, 1461-1470.

Enkhbayar, P., Kamiya, M., Osaki, M., Matsumoto, T. \& Matsushima, N. (2004). Structural principles of leucine-rich repeat (LRR) proteins. Proteins 54, 394-403.

Fernandez-Recio, J., Walas, F., Federici, L., Venkatesh Pratap, J., Bavro, V. N., Miguel, R. N., Mizuguchi, K. \& Luisi, B. (2004). A model of a transmembrane drug-efflux pump from Gram-negative bacteria. FEBS Lett 578, 5-9.

Finn, R. D., Mistry, J., Schuster-Böckler, B., Griffiths-Jones, S., Hollich, V., Lassmann, T., Moxon, S., Marshall, M., Khanna, A. \& other authors (2006). Pfam: clans, web tools and services. Nucleic Acids Res 34, D247-D251.

Fraser, M. E., James, M. N., Bridger, W. A. \& Wolodko, W. T. (1999). A detailed structural description of Escherichia coli succinyl-CoA synthetase. J Mol Biol 285, 1633-1653.

Gardy, J. L., Laird, M. R., Chen, F., Rey, S., Walsh, C. J., Ester, M. \& Brinkman, F. S. (2005). PSORTb v.2.0: expanded prediction of bacterial protein subcellular localization and insights gained from comparative proteome analysis. Bioinformatics 21, 617-623.

Hofmann, K. \& Stoffel, W. (1993). TMbase - a database of membrane spanning proteins segments. Biol Chem Hoppe Seyler 374, 166.

lida, Y. \& Mizokami, A. (1996). Outbreaks of coldwater disease in wild ayu and pale chub. Fish Pathol 31, 157-164.

Ikegami, A., Honma, K., Sharma, A. \& Kuramitsu, H. K. (2004). Multiple functions of the leucine-rich repeat protein LrrA of Treponema denticola. Infect Immun 72, 4619-4627.

Inagaki, S., Kuramitsu, H. K. \& Sharma, A. (2005). Contactdependent regulation of a Tannerella forsythia virulence factor, BspA, in biofilms. FEMS Microbiol Lett 249, 291-296.

Inagaki, S., Onishi, S., Kuramitsu, H. K. \& Sharma, A. (2006). Porphyromonas gingivalis vesicles enhance attachment, and the leucine-rich repeat BspA protein is required for invasion of epithelial cells by Tannerella forsythia. Infect Immun 74, 5023-5028.

Juncker, A. S., Willenbrock, H., Von Heijne, G., Brunak, S., Nielsen, H. \& Krogh, A. (2003). Prediction of lipoprotein signal peptides in Gramnegative bacteria. Protein Sci 12, 1652-1662.

Kasahara, M. \& Anraku, Y. (1974). Succinate- and NADH oxidase system in Escherichia coli membrane vesicles. J Biochem 76, 967-976.

Kobe, B. \& Kajava, A. V. (2001). The leucine-rich repeat as a protein recognition motif. Curr Opin Struct Biol 11, 725-732.

Kyte, J. \& Doolittle, R. F. (1982). A simple method for displaying the hydropathic character of a protein. J Mol Biol 157, 105-132.

Laemmli, U. K. (1970). Cleavage of structural proteins during the assembly of the head of bacteriophage T4. Nature 227, 680-685.

Le Hénaff, M. \& Fontenelle, C. (2000). Chemical analysis of processing of spiralin, the major lipoprotein of Spiroplasma melliferum. Arch Microbiol 173, 339-345.

Lun, S., Perez-Casal, J., Connor, W. \& Willson, P. J. (2003). Role of suilysin in pathogenesis of Streptococcus suis capsular serotype 2. Microb Pathog 34, 27-37.

MacLean, L. L., Vinogradov, E., Crump, E. M., Perry, M. B. \& Kay, W. W. (2001). The structure of the lipopolysaccharide O-antigen produced by Flavobacterium psychrophilum (259-93). Eur J Biochem 268, 2710-2716. 
Massias, B., Dumetz, F., Urdaci, M. C. \& Le Hénaff, M. (2004) Identification of $\mathrm{P} 18$, a surface protein produced by the fish pathogen Flavobacterium psychrophilum. J Appl Microbiol 97, 574-580.

Merle, C., Faure, D., Urdaci, M. C. \& Le Hénaff, M. (2003). Purification and characterization of a membrane glycoprotein from the fish pathogen Flavobacterium psychrophilum. J Appl Microbiol 94, 1120-1127.

Mistou, M. Y. \& Gripon, J. C. (1998). Catalytic properties of the cysteine aminopeptidase PepC, a bacterial bleomycin hydrolase. Biochim Biophys Acta 1383, 63-70.

Nielsen, H., Engelbrecht, J., Brunak, S. \& von Heijne, G. (1997). Identification of procaryotic and eucaryotic signal peptides and prediction of their cleavage sites. Protein Eng 10, 1-6.

Osborn, M. J. \& Munson, R. (1974). Separation of the inner (cytoplasmic) and outer membranes of Gram-negative bacteria. Methods Enzymol 31, 642-653.

Pearson, W. R. (1990). Rapid and sensitive sequence comparison with FASTP and FASTA. Methods Enzymol 183, 63-98.

Rahman, H., Kuroda, A., Dijkstra, J. M., Kiryu, I., Nakanishi, T. \& Ototake, M. (2002). The outer membrane fraction of Flavobacterium psychrophilum induces protective immunity in rainbow trout and ayu. Fish Shellfish Immunol 12, 169-179.

Rhomberg, T. A., Karlberg, O., Mini, T., Zimny-Arndt, U., Wickenberg, U., Röttgen, M., Jungblut, P. R., Jenö, P., Andersson, S. G. \& Dehio, C. (2004). Proteomic analysis of the sarcosine-insoluble outer membrane fraction of the bacterial pathogen Bartonella henselae. Proteomics 4, 3021-3033.

Sankaran, K., Gupta, S. D. \& Wu, H. C. (1995). Modification of bacterial lipoproteins. Methods Enzymol 250, 683-697.

Santoni, V., Molloy, M. \& Rabilloud, T. (2000). Membrane proteomics: use of additive main effects with multiplicative interaction model to classify plasma membrane proteins according to their solubility and electrophoretic properties. Electrophoresis 21, 1054-1070.

Saul, F. A., Arié, J. P., Vulliez-le Normand, B., Kahn, R., Betton, J. M. \& Bentley, G. A. (2004). Structural and functional studies of FkpA from Escherichia coli, a cis/trans peptidyl-prolyl isomerase with chaperone activity. J Mol Biol 335, 595-608.

Schäffer, A. A., Aravind, L., Madden, T. L., Shavirin, S., Spouge, J. L., Wolf, Y. I., Koonin, E. V. \& Altschul, S. F. (2001). Improving the accuracy of PSI-BLAST protein database searches with compositionbased statistics and other refinements. Nucleic Acids Res 29, 29943005.

Secades, P., Alvarez, B. \& Guijarro, J. A. (2001). Purification and characterization of a psychrophilic, calcium-induced, growth-phasedependent metalloprotease from the fish pathogen Flavobacterium psychrophilum. Appl Environ Microbiol 67, 2436-2444.

Secades, P., Alvarez, B. \& Guijarro, J. A. (2003). Purification and properties of a new psychrophilic metalloprotease (Fpp2) in the fish pathogen Flavobacterium psychrophilum. FEMS Microbiol Lett 226, 273-279.

Sharma, A., Sojar, H. T., Glurich, I., Honma, K., Kuramitsu, H. K. \& Genco, R. J. (1998). Cloning, expression, and sequencing of a cell surface antigen containing a leucine-rich repeat motif from Bacteroides forsythus ATCC 43037. Infect Immun 66, 5703-5710.

Smith, S. G., Mahon, V., Lambert, M. A. \& Fagan, R. P. (2007). A molecular Swiss army knife: OmpA structure, function and expression. FEMS Microbiol Lett 273, 1-11.

Sudheesh, P. S., LaFrentz, B. R., Call, D. R., Siems, W. F., LaPatra, S.-E., Wiens, G. D. \& Cain, K. D. (2007). Identification of potential vaccine target antigens by immunoproteomic analysis of a virulent and a non-virulent strain of the fish pathogen Flavobacterium psychrophilum. Dis Aquat Organ 74, 37-47.

Takamatsu, D., Osaki, M. \& Sekizaki, T. (2002). Evidence for lateral transfer of the suilysin gene region of Streptococcus suis. J Bacteriol 184, 2050-2057.

Wexler, H. M., Read, E. K. \& Tomzynski, T. J. (2002). Characterization of omp200, a porin gene complex from Bacteroides fragilis: omp121 and omp71, gene sequence, deduced amino acid sequences and predictions of porin structure. Gene 283, 95-105.

Wyckoff, E. E., Mey, A. R., Leimbach, A., Fisher, C. F. \& Payne, S. M. (2006). Characterization of ferric and ferrous iron transport systems in Vibrio cholerae. J Bacteriol 188, 6515-6523.

Yang, Y., Merriam, J. J., Mueller, J. P. \& Isberg, R. R. (1996). The psa locus is responsible for thermoinducible binding of Yersinia pseudotuberculosis to cultured cells. Infect Immun 64, 2483-2489.

Edited by: David M. Gordon 